\title{
Foreign exchange risk management practices by Jordanian nonfinancial firms
}

\author{
Riad Al-Momani*, and Mohammad R. Gharaibeh \\ *Department of Economics, Yarmouk University, Jordan-Irbed. \\ Fax: 09626 5063042, E-mail: ralmomani2000@yahoo.com \\ Received (in revised form): 21st June, 2008
}

Riad Al-Momani is Professor of Economics at the Yarmouk University, Jordan. He graduated from the Utah State University, USA, in 1985. He has published many papers in national and regional journals. His research interests include economic development and finance issues, and portfolio management.

Mohammad R. Gharaibeh is a graduate student in Yarmouk University.

\begin{abstract}
Foreign exchange risk becomes more and more important in light of the globalisation and internationalisation of world markets, and is one of the most difficult and persistent problems with which the financial executives must cope. This study concentrates on the foreign exchange risk management practices of Jordanian firms, and examines the relationship between various factors that are presumed to affect the adopting of foreign exchange risk management techniques, namely firm size, sector, international business involvement, and legal structure. The study focuses on transaction and economic exposures as the dimensions of foreign exchange risk management techniques. The results are taken from an empirical field study of 73 nonfinancial firms listed by Jordan's Income and Sales Tax Department as major taxpayers. The study uses the Kruskal-Wallis oneway analysis of variances to analyse the data. The results indicate that the use of foreign exchange risk management techniques such as financial derivatives is not a common practice by Jordanian firms. The most common methods used by firms to counter foreign exchange risks such as matching, netting, using local
\end{abstract}

currency, and price policy are internal (natural) resources. In addition, this study concludes that there are no relationships between firm size and legal structure and the management practices toward transaction exposure. A relationship between a firm's sector and international involvement with the management practices was found in the transaction exposure dimension. Concerning the economic exposure dimension, a relationship between all the characteristics and the managerial techniques is found. This study recommends proper training programmes for financial managers in order to enhance their knowledge about the importance of foreign currency risk and the different techniques used to manage that risk.

Journal of Derivatives \& Hedge Funds (2008) 14, 198-221. doi:10.1057/jdhf.2008.16

Keywords: foreign exchange risk; exchange rate risk; currency risk; transaction

\section{PREFACE}

In an era of globalisation and internationalisation, the economic environment
Journal of Derivatives \& Hedge Funds, Vol. 14 Nos. 3/4, 2008, pp. 198-221 (C) 2008 Palgrave Macmillan 1753-9641 
in which most firms operate is highly volatile and uncertain. This volatility can be reflected in increased fluctuations in foreign exchange and interest, and inflation rates; increased competition, demand levels, etc. In addition, the extensive use of financial innovations and the advances in financial instruments to manage this risk make this issue one of a firm's priorities.

Foreign currency risk is a crucial factor that affects most firms, especially those that trade frequently in international markets. This is so because if a firm buys a foreign asset, it is exposed to two types of risk: the first is related to the value of the asset, while the other is related to the fluctuations in exchange rates. In other words, an overseas contract, which is profitable at the time of the deal, may become unprofitable if the exchange rates changes. This is an example of the direct exposure to movements in exchange rates; however, the exposure can have an indirect effect through pricing strategy changes, labour costs, etc. In addition, the growth in the size of international trade makes foreign currency risk an important issue for a whole range of companies.

This study explores the areas of foreign currency risk management, with a special emphasis on specific forms of that exposure, namely transaction and economic exposures. Translation risk is ignored because of the small number of multinational firms based in Jordan exposed to such risk. In addition, the analysis involves only selected nonfinancial companies as the sample of the study. Financial companies were neglected because of the ambiguity concerning the purpose of their use of hedging instruments.

Currently, there is a scarcity of research papers about foreign exchange risk management in emerging markets. Theoretical studies are usually supported by findings from developed countries. ${ }^{1}$ Therefore, this study will be distinctive, because it will contribute to the increase in academic studies on emerging markets. In addition, it concentrates on Jordan, one of the Middle Eastern countries, which makes it one of the first studies in this area.

\section{COMMENTS ON PREVIOUS STUDIES}

Previous studies have been conducted regarding different objectives and visions of the foreign exchange rate risk. Allayannis et al. ${ }^{2}$ dealt with the rationality behind managing such a risk.

Many studied the impact of exchange rate movements on a firm, such as Karasoy, ${ }^{3}$ Bradly and Moles, ${ }^{4}$ El-Masry, ${ }^{5}$ and Fang and Miller. ${ }^{6}$ An investigation of the wide use of exchange rate risk management techniques was conducted by Belk and Glaum, ${ }^{7}$ Batten, et al., ${ }^{8}$ and Jonuska and Samenaite. ${ }^{1}$ Other studies were conducted to examine the theory about foreign exchange risk management and what is done in practice, such as Brucaite and Yan, ${ }^{9}$ Dhanani and Groves, ${ }^{10}$ and Popov and Stutzmann. ${ }^{11}$

Most of the literature has been supported. There are a lot of studies in the developed countries. However, very few studies were found to support cases in developing countries. Such a study is a distinguishing feature because it is conducted on Jordanian firms as a study case and Jordan is considered one of the developing countries in the Middle East.

\section{PROBLEM DEFINITION}

As mentioned earlier, there is a scarcity of studies and papers concerning foreign currency risk exposure and management in developing countries. Therefore, to achieve a good start in this area is to study and identify factors that are 
presumed to affect the management of foreign currency risk. This study investigates a problem that can be defined through the following questions:

(1) Do Jordanian corporations adopt or implement foreign exchange risk management techniques?

(2) What kind of foreign exchange risk management do Jordanian corporations mostly use?

(3) Do firm-specific characteristics affect the level of adoption of foreign exchange risk management techniques in the Jordanian environment?

\section{OBJECTIVES OF THE STUDY}

The main objective of this study is to investigate the relationship between foreign currency risk and international business involvement, legal structure, firm size, sector, and management practices in the Jordanian environment.

The impact of firm-specific characteristics on the managerial practices of Jordanian firms will also be investigated, by examining the opinions of financial controllers, treasury managers or persons involved in foreign exchange management decisions.

\section{MAIN HYPOTHESIS}

In order to conduct this study, the following hypotheses will be tested:

1H0: There is a significant statistical relationship between a firm's international business involvement level and management practices and transaction exposure in the Jordanian environment.
2H0: There is a significant statistical relationship between a firm's legal structure and management practices and transaction exposure risk in the Jordanian environment.

3H0: There is a significant statistical relationship between firm size and management practices and transaction exposure in the Jordanian environment.

4H0: There is a significant statistical relationship between a firm's sector and management practices and transaction exposure in the Jordanian environment.

5H0: There is a significant statistical relationship between a firm's international business involvement level and management practices and economic exposure in the Jordanian environment.

6H0: There is a significant statistical relationship between a firm's legal structure and management practices and economic exposure risk in the Jordanian environment.

7H0: There is a significant statistical relationship between firm size and management practices and economic exposure in the Jordanian environment.

8H0: There is a significant statistical relationship between a firm's sector and management practices and economic exposure in the Jordanian environment.

\section{METHODOLOGY}

Because there is no common methodology or generally accepted design that fits the topic of this research, the research methodology has been 


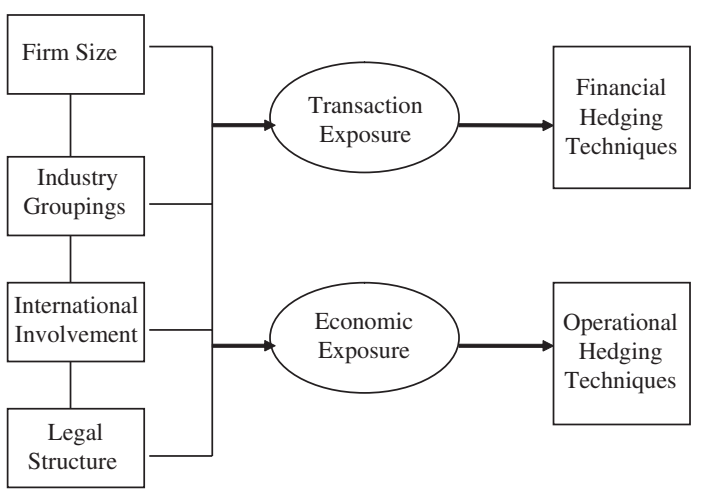

Figure 1: Model of the study

developed in a way that demonstrates the model of the study, dimensions of the study, hypotheses and the aspects related to sampling, data and methods of statistical analysis.

\section{Model of the study}

The following chart (Figure 1) shows the firmspecific characteristics as the independent variables, which are firm size, industry sector, international business activities, ownership, and legal structure. These independent variables will present relations under two dimensions of dependent variables: the financial hedging techniques and the operational hedging techniques.

\section{Variables of the study}

The focus of the study is the question of what determines the method that firms in Jordan use to manage transaction and economic exposures. Consequently, the hedging strategies that the Jordanian firms adopted are designed as dependent variables.

\section{The dependent variables}

(1) Financial hedging techniques. These techniques are used to hedge transaction exposure, and they are different from each other in terms of their sophistication levels. It starts with using internal hedging techniques, and then moves to a more complex hedge by using money market techniques and currency derivatives. However, the latter represent a more risky and expensive instrument to hedge the transaction exposure.

(2) Operational hedging techniques. These techniques are used to hedge economic exposure. They are also different in terms of risk and cost levels. They start to source inputs in the same currencies as sales which can finally be used to conduct major actions such as altering the currency that production/operations occur following movements in foreign exchange rates.

\section{The independent variables}

Company-specific characteristics are used to establish the study of relations to the management practices concerning foreign currency risk.

These characteristics are as follows:

(1) Firm size. Total annual sales, equity capital (capital raised from owners), and market value of a firm's assets used as proxies for a firm size.

(2) International business involvement. This characteristic is concerned with the degree of involvement of a firm in the foreign environment. Three variables are used as proxies for measuring the degree of foreign involvement: (1) percentage of foreign currency sales to total sales (FS/TS),

(2) percentage of foreign currency costs to total costs (FC/TC), (3) percentage 
of foreign currency debt to total debt (FD/TD).

(3) Firm's sector. The financial and operational hedging techniques across different industries are examined. The research covers Jordanian commercial, manufacturing, and other firms (mining and processing, agriculture, and building and construction).

(4) The legal form of the firms. The main legal forms of Jordanian firms are sole trader, partnership, closed limited corporations and public limited corporations.

The main different characteristics of the firms are presumed to have effects on foreign currency exposure due to the different structures, markets and cash flows of the firms.

\section{POPULATION AND SAMPLE OF THE STUDY}

This study was performed by exploring the impact of selected company-specific characteristics on the adoption of foreign currency risk management techniques. To achieve this goal, a sample of the largest nonfinancial firms, in terms of annual sales and annual income, operating in Jordan was used as a unit of analysis. There were 456 firms. Only 310 firms from different sectors and types met the criteria of the study. ${ }^{12}$

The population of the study was sub-grouped in terms of economic sectors into three strata (sub-groups), which are manufacturing, commercial, and other sectors. These subgroups are unequal in size: it is preferable to use proportionate (unequal size) stratified random sampling to represent the three sub-groups. This ensures the selection of a representative sample. Thus, 120 firms were selected: 45 manufacturing firms, 60 commercial firms, and 15 firms from other sectors.

\section{Data collection techniques}

Data needed for this study were collected from two sources: secondary and primary.

\section{Secondary sources}

The secondary source represents the related information that was found in books, articles, periodicals, working papers, e-papers, and unpublished studies such as dissertations and theses, in addition to some related and valuable websites.

\section{Primary sources}

One primary source was a questionnaire written in Arabic using scales such as itemised rating scales, which are effective for measuring anchors as needed. In addition, category scales were used to identify specific characteristics of the subject. The questionnaire consists of three parts, representing general information on the subjects, a transaction exposure section, and an economic exposure section. Finally, a summary of some techniques for foreign currency risk management is provided in order to ensure the full understanding of the question asked.

The questionnaire was distributed to the respondents, completed by them at their work locations and returned to the researcher. They were reminded one to two days before the due date to return the questionnaire, if they had not already done so. The respondents targeted were mainly financial managers and/or treasurers. 


\section{Data analysis techniques}

To test the hypotheses, the study employed some known statistical techniques. To measure the central tendency and dispersion, descriptive statistics were employed such as frequencies, ratios, means and standard deviations. The Kruskal-Wallis one-way analysis of variances (ANOVA) was used to examine the significance of statistical differences. This technique compares the variances between groups with the variances within groups. In case such significant statistical differences between groups do exist, the one-way ANOVA is used when the dependent variable is on an ordinal scale, and the independent variables are normally scaled.

\section{Data analysis/major results}

This section presents and analyses the data obtained by the questionnaire. The goodness of data was examined using the statistical techniques mentioned above.

\section{Responding rates}

The data needed were obtained through the distribution of 120 questionnaires to three strata of firms in a proportionate manner to their total size in the population.
The groups of respondents are commercial, manufacturing, and other firms. Out of the 87 questionnaires returned, 72.5 per cent was the retrieval rate, as only 73 copies were considered valid for analysis, which represents a response rate of about 61 per cent.

The response rates and the number of valid questionnaires retrieved by each group are shown next in Table 1.

Because of the leading questions in the questionnaire, some companies in the sample did not answer all paragraphs of the questionnaire.

The number and percentages for the paragraphs are shown in Table 2.

\section{Validity of the research tool}

Structured questionnaires were prepared to accomplish the objective of this research. The questionnaire was first approved by three qualified professors at Yarmouk University and was then tested in the field. The mistakes and ambiguous items were corrected and amended through the field observations. The reliability analysis for the questionnaire was carried using a sample of 15 firms. Cronbach's coefficient alpha was also estimated. The results show that the Cronbach's alpha values for the items related to transaction and economic risk were 0.90 and 0.72 ,

\section{Table 1: Response rates}

\begin{tabular}{|c|c|c|c|c|c|c|}
\hline \multirow[t]{2}{*}{ Group } & \multicolumn{2}{|c|}{ No. of questionnaires } & \multirow{2}{*}{$\begin{array}{l}\text { Retrieval } \\
\text { rate (\%) }\end{array}$} & \multicolumn{2}{|c|}{ No. of questionnaires } & \multirow{2}{*}{$\begin{array}{l}\text { Net response } \\
\text { rate }(\%)\end{array}$} \\
\hline & Distributed & Returned & & Invalid3 & Valid & \\
\hline Commercial firms & 60 & 45 & 75 & 11 & 34 & 56 \\
\hline Manufacturing firms & 45 & 33 & 73 & 2 & 31 & 69 \\
\hline Other & 15 & 9 & 60 & 1 & 8 & 53 \\
\hline Total & 120 & 87 & 72.5 & 14 & 73 & 61 \\
\hline
\end{tabular}


Table 2: Response rates for each question

\begin{tabular}{|c|c|c|}
\hline Question & Frequency & Valid $\%$ \\
\hline Sectors of the firm & 73 & 100.0 \\
\hline Firms legal structure & 73 & 100.0 \\
\hline Annual sales of the firms & 67 & 91.8 \\
\hline Firm's capital & 70 & 95.9 \\
\hline Percentage of foreign sale's to total sales & 70 & 95.9 \\
\hline Percentage of foreign cost's to total cost's & 70 & 95.9 \\
\hline Percentage of foreign debt to total debt & 73 & 100.0 \\
\hline Existence of $\mathrm{A} / \mathrm{P}$ and $\mathrm{A} / \mathrm{R}$ & 73 & 100.0 \\
\hline Managing foreign currency risk & 42 & 57.5 \\
\hline Purpose of managing currency risk & 28 & 38.3 \\
\hline Effect of exchange rate variations on the firms activities & 64 & 87.6 \\
\hline Effect of capital size on managing transaction exposure risk & 36 & 49.3 \\
\hline Effect of sales volume on managing transaction exposure risk & 39 & 53.4 \\
\hline Effect of firm's sector on transaction exposure risk & 38 & 52.0 \\
\hline Percentage of FS/TS sales effect on transaction exposure risk management & 39 & 53.4 \\
\hline Percentage of FC/TC sales effect on transaction exposure risk management & 39 & 53.4 \\
\hline Percentage of FD/TD sales effect on transaction exposure risk management & 39 & 53.4 \\
\hline Legal structure effect on transaction exposure risk management & 38 & 52.0 \\
\hline Effect of capital size on managing economic exposure risk & 55 & 75.3 \\
\hline Effect of sales volume on managing economic exposure risk & 52 & 71.2 \\
\hline Effect of firms sector on managing economic exposure risk & 57 & 78.0 \\
\hline Percentage of FS/TS sales effect on economic exposure risk management & 54 & 73.9 \\
\hline Percentage of FC/TC sales effect on economic exposure risk management & 54 & 73.9 \\
\hline Percentage of FD/TD sales effect on economic exposure risk management & 58 & 79.4 \\
\hline Legal structure effect on economic exposure risk management & 57 & 78.0 \\
\hline
\end{tabular}

respectively, while the value for all items was 0.87 . These values of Cronbach's alpha are acceptable for studies such as the current one (Table 3).

\section{Hypotheses testing}

This section is devoted to testing the previously mentioned hypotheses of the study. The hypotheses mainly aim to find significant relationships between presumed factors (firmspecific characteristics) and the management techniques of foreign currency risk.

Firm-specific characteristics are related to management techniques under two dimensions: transaction exposure management and economic exposure management.

Since there are more than two independent variables (firm-specific characteristics) and the 
Table 3: Cronbach's coefficient alpha

\begin{tabular}{lll}
\hline Dimension & $\begin{array}{l}\text { No. of } \\
\text { items }\end{array}$ & $\begin{array}{l}\text { Cronbach's } \\
\text { coefficient alpha }\end{array}$ \\
\hline Transaction risk & 5 & 0.90 \\
Economic risk & 3 & 0.72 \\
All items & 8 & 0.87 \\
\hline
\end{tabular}

dependent variables (management techniques for each dimension) are measured on an interval scale, ANOVA is appropriate for testing these hypotheses.

\section{The results of transaction exposure dimension}

Transaction exposure is related to the risk that arises from day-to-day transactions dealt with foreign currencies that are subject to volatility in value against the local currency.

In order to obtain results concerning whether there is a relationship between the firm-specific characteristics and foreign currency risk management techniques adopted by Jordanian firms, different techniques were listed. To show how often they were used, answers were coded in such a way that if a technique was always used by a firm, the code was (5); if it was usually used, the code was (4); if it was sometimes used, the code was (3); if it was seldom used, the code was (2); and finally if the technique was never used, the code was (1).

(1) The effect of firm size on managing transaction exposure risk

Firm size is expressed by two variables: capital and sales volume of a firm. The hypothesis is as follows:

H01: There is a significant statistical relationship between firm size and management practices and transaction exposure in the Jordanian environment.

The one-way ANOVA results for each variable are as follows:

(a) The effect of the capital size of a firm on managing transaction exposure risk

As Table 4 shows, with a significant level of 0.074 , there is no significant statistical relationship between the capital size of a firm and the techniques used to manage transaction exposure. This considers 0.05 significance level or below as the acceptable level for social science studies.

(b) The effect of the sales volume of a firm on managing transaction exposure risk

The result of the sales volume character and its relation to the use of transaction exposure management techniques (as shown in Table 5) indicates an insignificant statistical relation. The significance level for this test is $(=0.218>0.05)$, which is not acceptable.

Both results assert the rejection of the hypothesis of the significant statistical relationship between firm size and the management of transaction exposure.

(2) The effect of firm sector on managing transaction exposure risk

H02: There is a significant statistical relationship between firm sector and management practices and transaction exposure in the Jordanian environment.

Table 6 shows that there is a significant statistical relationship between the sector of a firm and the techniques used. The significant level of 0.028 is lower than 0.05 . This implies 
Table 4: The effect of capital size on managing transaction exposure risk

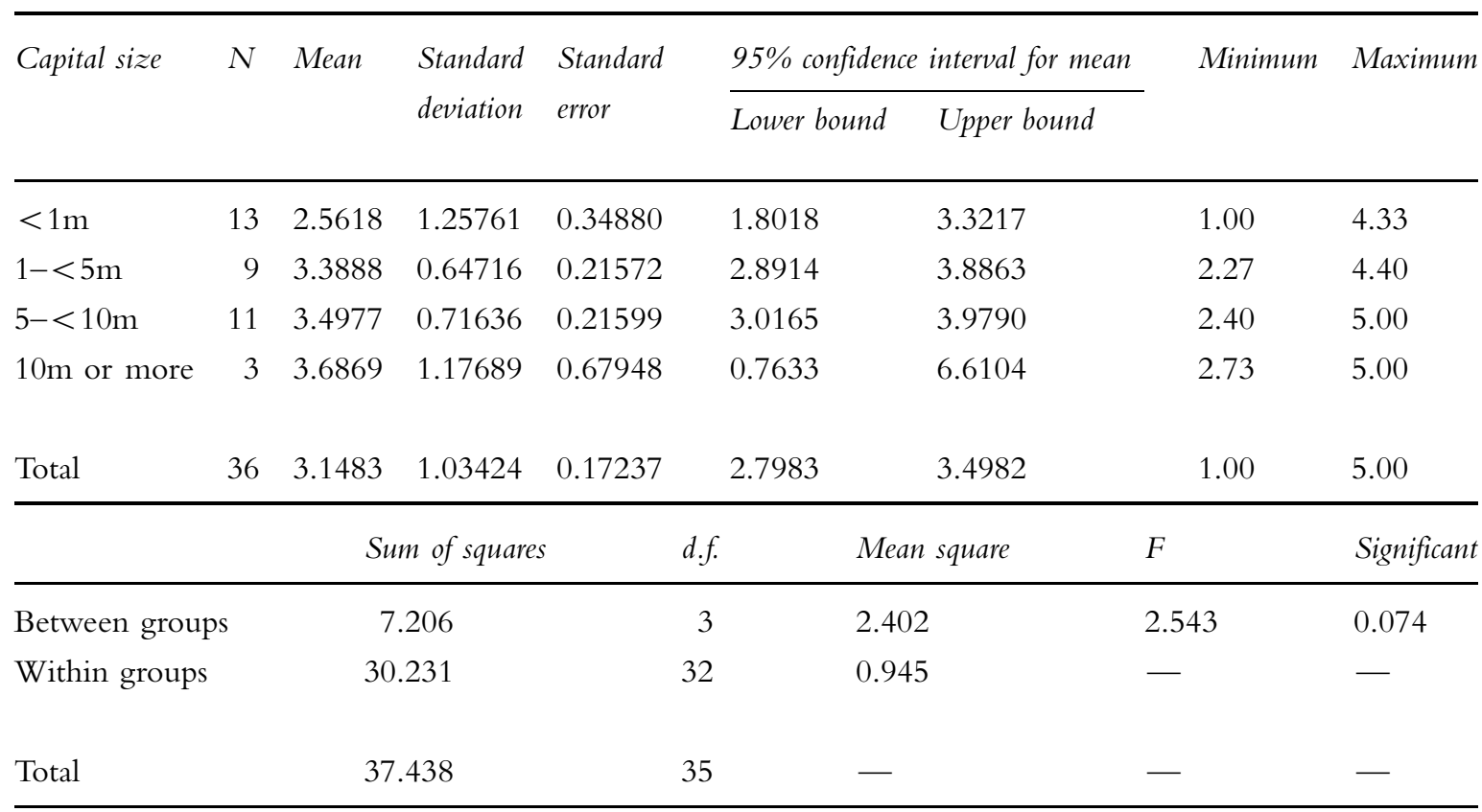

Table 5: The effect of sales volume on managing transaction exposure risk

\begin{tabular}{|c|c|c|c|c|c|c|c|c|c|}
\hline \multirow[t]{2}{*}{ Sales volume } & \multirow[t]{2}{*}{$N$} & \multirow[t]{2}{*}{ Mean } & \multirow{2}{*}{$\begin{array}{l}\text { Standard } \\
\text { deviation }\end{array}$} & \multirow{2}{*}{$\begin{array}{l}\text { Standard } \\
\text { error }\end{array}$} & \multicolumn{3}{|c|}{ 95\% confidence interval for mean } & \multirow[t]{2}{*}{ Minimum } & \multirow[t]{2}{*}{ Maximum } \\
\hline & & & & & & Lower bound & Upper bound & & \\
\hline$<3 \mathrm{~m}$ & 8 & 2.3523 & 1.62872 & 0.57584 & & 0.9906 & 3.7139 & 1.00 & 5.00 \\
\hline $3-6 m$ & 15 & 3.1988 & 0.70348 & 0.18164 & & 2.8092 & 3.5884 & 2.00 & 4.40 \\
\hline $6-9 \mathrm{~m}$ & 6 & 3.6015 & 0.43486 & 0.17753 & & 3.1452 & 4.0579 & 3.00 & 4.00 \\
\hline $9-12 \mathrm{~m}$ & 4 & 3.5476 & 0.55737 & 0.27868 & & 2.6607 & 4.4345 & 2.86 & 4.00 \\
\hline $13-15 m$ & 2 & 3.3667 & 1.36707 & 0.96667 & & -8.9160 & 15.6493 & 2.40 & 4.33 \\
\hline $15 \mathrm{~m}$ or more & 4 & 3.4318 & 1.06374 & 0.53187 & & 1.7392 & 5.1245 & 2.73 & 5.00 \\
\hline \multirow[t]{2}{*}{ Total } & 39 & 3.1554 & 1.02638 & 0.16435 & & 2.8227 & 3.4881 & 1.00 & 5.00 \\
\hline & & \multicolumn{2}{|c|}{ Sum of squares } & \multicolumn{2}{|r|}{ d.f. } & \multicolumn{2}{|c|}{ Mean square } & $F$ & Significant \\
\hline \multicolumn{2}{|c|}{ Between groups } & \multicolumn{2}{|c|}{7.393} & \multicolumn{2}{|r|}{5} & \multicolumn{2}{|c|}{1.479} & 1.495 & 0.218 \\
\hline \multicolumn{2}{|l|}{ Within groups } & \multicolumn{2}{|c|}{32.639} & \multicolumn{2}{|r|}{33} & \multicolumn{2}{|c|}{0.989} & - & - \\
\hline \multicolumn{2}{|l|}{ Total } & \multicolumn{2}{|c|}{40.031} & & 38 & \multicolumn{2}{|c|}{ - } & - & - \\
\hline
\end{tabular}


Table 6: The effect of firm's sector on transaction exposure risk

\begin{tabular}{|c|c|c|c|c|c|c|c|c|}
\hline \multirow[t]{2}{*}{ Firm's sector } & \multirow[t]{2}{*}{$N$} & \multirow[t]{2}{*}{ Mean } & \multirow{2}{*}{$\begin{array}{l}\text { Standard } \\
\text { deviation }\end{array}$} & \multirow{2}{*}{$\begin{array}{l}\text { Standard } \\
\text { error }\end{array}$} & \multicolumn{2}{|c|}{$95 \%$ confidence interval for mean } & \multirow[t]{2}{*}{ Minimum } & \multirow[t]{2}{*}{ Maximum } \\
\hline & & & & & Lower bound & Upper bound & & \\
\hline Manufacturing & 18 & 3.4440 & 0.74343 & 0.17523 & 3.0743 & 3.8137 & 2.00 & 5.00 \\
\hline Commercial & 19 & 2.7931 & 1.13568 & 0.26054 & 2.2457 & 3.3405 & 1.00 & 4.40 \\
\hline Others & 1 & 5.0000 & - & - & - & - & 5.00 & 5.00 \\
\hline \multirow[t]{2}{*}{ Total } & 38 & 3.1595 & 1.03984 & 0.16868 & 2.8177 & 3.5013 & 1.00 & 5.00 \\
\hline & & \multicolumn{2}{|c|}{ Sum of squares } & \multicolumn{2}{|c|}{ d.f. } & $n$ square & $F$ & Significant \\
\hline \multicolumn{2}{|l|}{ Between groups } & \multicolumn{2}{|c|}{7.395} & \multicolumn{2}{|c|}{2} & & 3.968 & 0.028 \\
\hline \multicolumn{2}{|l|}{ Within groups } & \multicolumn{2}{|c|}{32.612} & \multicolumn{2}{|c|}{35} & & - & - \\
\hline Total & & \multicolumn{2}{|c|}{40.007} & \multicolumn{2}{|c|}{37} & & - & - \\
\hline
\end{tabular}

that the hypothesis $(\mathrm{H} 02)$ is substantiated. The results show that the strongest attitude toward adopting the managerial techniques was in manufacturing, as the mean is 3.44 . This was followed by wholesale and retail trade, with a mean of 2.79. Although other sectors have a mean of 5.0, this result was neglected because only one respondent responded to that question.

\section{(3) The effect of international involvement on} managing transaction exposure risk

This section tests the following hypothesis:

H03: There is a significant statistical relationship between international business activity level and management practices and transaction exposure in the Jordanian environment.

As mentioned earlier, this factor is measured using three variables. The results for each variable are presented next. (a) The effect of percentage of foreign sales to total sales on transaction exposure risk management

A significant statistical relationship, at significance $\alpha=0.05$, is clearly shown in Table 7 .

(b) The effect of percentage of foreign costs to total costs on foreign transaction exposure risk management Table 8 represents the test of the relationship between foreign costs percentage with the use of transaction exposure management techniques. The results show a significant statistical relationship, with a significance level of 0.0001 .

(c) The effect of percentage of foreign debt to total debt on foreign transaction exposure risk management Table 9 demonstrates that there is no significant statistical relationship with this variable.

In order to accept or reject the hypothesis of the relation between the international business activities of a firm and its management of transaction exposure, the previous three variables 
Table 7: Percentage of foreign sales to total sales effect on transaction exposure currency risk management

\begin{tabular}{|c|c|c|c|c|c|c|c|c|c|}
\hline \multirow{2}{*}{$\begin{array}{l}\text { Percentage of } \\
\text { FS/TS }\end{array}$} & \multirow{2}{*}{$N$} & \multirow[t]{2}{*}{ Mean } & \multirow{2}{*}{$\begin{array}{l}\text { Standard } \\
\text { deviation }\end{array}$} & \multirow{2}{*}{$\begin{array}{l}\text { Standard } \\
\text { error }\end{array}$} & \multicolumn{3}{|c|}{$95 \%$ confidence interval for mean } & \multirow[t]{2}{*}{ Minimum } & \multirow[t]{2}{*}{ Maximum } \\
\hline & & & & & & Lower bound & Upper bound & & \\
\hline 0 & 5 & 2.8667 & 0.81989 & 0.36667 & & 1.8486 & 3.8847 & 2.50 & 4.33 \\
\hline 10 & 5 & 1.4909 & 1.09771 & 0.49091 & & 0.1279 & 2.8539 & 1.00 & 3.45 \\
\hline 20 & 4 & 3.8333 & 0.33333 & 0.16667 & & 3.3029 & 4.3637 & 3.33 & 4.00 \\
\hline 30 & 5 & 3.3891 & - & 0.43407 & & 2.1839 & 4.5943 & 2.40 & 5.00 \\
\hline 40 & 7 & 3.4208 & 0.87233 & 0.32971 & & 2.6140 & 4.2275 & 2.00 & 4.40 \\
\hline 50 & 5 & 3.8273 & 0.82597 & 0.36939 & & 2.8017 & 4.8529 & 2.73 & 5.00 \\
\hline 60 & 2 & 3.2667 & 0.09428 & 0.06667 & & 2.4196 & 4.1137 & 3.20 & 3.33 \\
\hline 70 & 2 & 3.4167 & 0.11785 & 0.08333 & & 2.3578 & 4.4755 & 3.33 & 3.50 \\
\hline 80 & 2 & 3.4545 & 0.89995 & 0.63636 & & -4.6312 & 11.5403 & 2.82 & 4.09 \\
\hline 100 & 2 & 2.8182 & 0.77139 & 0.54545 & & -4.1125 & 9.7488 & 2.27 & 3.36 \\
\hline \multirow[t]{2}{*}{ Total } & 39 & 3.1554 & 1.02638 & 0.16435 & & 2.8227 & 3.4881 & 1.00 & 5.00 \\
\hline & & \multicolumn{3}{|c|}{ Sum of squares } & d.f. & \multicolumn{2}{|c|}{ Mean square } & $F$ & Significant \\
\hline \multicolumn{2}{|c|}{ Between groups } & \multicolumn{2}{|c|}{19.699} & \multicolumn{2}{|r|}{9} & \multicolumn{2}{|c|}{2.189} & 3.122 & 0.009 \\
\hline \multicolumn{2}{|c|}{ Within groups } & \multicolumn{2}{|c|}{20.333} & \multicolumn{2}{|c|}{29} & \multicolumn{2}{|c|}{0.701} & - & - \\
\hline \multicolumn{2}{|l|}{ Total } & \multicolumn{2}{|c|}{40.031} & & 38 & \multicolumn{2}{|c|}{-} & - & - \\
\hline
\end{tabular}

must be considered. The degree of international involvement of a firm was measured by $\% \mathrm{FS}$ (percentage of foreign sales), $\% \mathrm{FC}$ (percentage of foreign costs), and \% $\mathrm{FD}$ (percentage of foreign debt).

Both \%FS and \%FC showed a significant statistical relationship with the use of the management techniques, but \%FD showed no relation. The sample results of that specific variable, however, showed that 42.4 per cent of firms had no debt in foreign currency at all. Also, 83.4 per cent of firms had a \%FD of 50 per cent or less and this weakens the reliability of this variable. Therefore, the variables $\% \mathrm{FS}$ and $\% \mathrm{FC}$ are more reliable in determining the result of the test for that hypothesis.

Finally, considering the results of $\% \mathrm{FS}$ and $\% \mathrm{FC}$ and their significance level, H03 is substantiated.

(4) The effect of legal structure on foreign transaction exposure risk management

The hypothesis is as follows:

H04: There is a significant statistical relationship between legal structure and management practices and transaction exposure risk in the Jordanian environment. 
Table 8: Percentage of foreign costs to total costs effect on transaction exposure risk management

\begin{tabular}{|c|c|c|c|c|c|c|c|c|}
\hline \multirow{2}{*}{$\begin{array}{l}\text { Percentage of } \\
F C / T C\end{array}$} & \multirow{2}{*}{$N$} & \multirow{2}{*}{ Mean } & \multirow{2}{*}{$\begin{array}{l}\text { Standard } \\
\text { deviation }\end{array}$} & \multirow{2}{*}{$\begin{array}{l}\text { Standard } \\
\text { error }\end{array}$} & \multicolumn{2}{|c|}{$95 \%$ confidence interval for mean } & \multirow[t]{2}{*}{ Minimum } & \multirow[t]{2}{*}{ Maximum } \\
\hline & & & & & Lower bounc & Upper bound & & \\
\hline 0 & 1 & 1.0909 & - & - & - & - & 1.09 & 1.09 \\
\hline 10 & 4 & 1.0000 & 0.00000 & 0.00000 & 1.0000 & 1.0000 & 1.00 & 1.00 \\
\hline 30 & 2 & 3.9091 & 1.54278 & 1.09091 & -9.9522 & 17.7704 & 2.82 & 5.00 \\
\hline 40 & 1 & 2.0000 & - & - & - & - & 2.00 & 2.00 \\
\hline 50 & 2 & 3.1000 & 0.14142 & 0.10000 & 1.8294 & 4.3706 & 3.00 & 3.20 \\
\hline 60 & 3 & 3.2121 & 0.61881 & 0.35727 & 1.6749 & 4.7493 & 2.73 & 3.91 \\
\hline 70 & 8 & 3.6940 & 0.42059 & 0.14870 & 3.3423 & 4.0456 & 3.33 & 4.33 \\
\hline 80 & 12 & 3.4128 & 0.86226 & 0.24891 & 2.8650 & 3.9607 & 2.50 & 5.00 \\
\hline 90 & 5 & 3.3073 & 0.61100 & 0.27325 & 2.5486 & 4.0659 & 2.40 & 4.09 \\
\hline 100 & 1 & 2.2727 & - & - & - & - & 2.27 & 2.27 \\
\hline \multirow[t]{2}{*}{ Total } & 39 & 3.1554 & 1.02638 & 0.16435 & 2.8227 & 3.4881 & 1.00 & 5.00 \\
\hline & & \multicolumn{3}{|c|}{ Sum of squares } & \multicolumn{2}{|c|}{ Mean square } & $F$ & Significant \\
\hline \multicolumn{2}{|c|}{ Between groups } & \multicolumn{2}{|c|}{25.955} & & 9 & & 5.942 & 0.000 \\
\hline \multicolumn{2}{|c|}{ Within groups } & \multicolumn{2}{|c|}{14.076} & & 29 & & - & - \\
\hline \multicolumn{2}{|l|}{ Total } & \multicolumn{3}{|c|}{40.031} & \multicolumn{2}{|c|}{ - } & - & - \\
\hline
\end{tabular}

The results show that there is no significant statistical relationship between the legal structure of a firm and its management of transaction exposure. Therefore, $\mathrm{H} 04$ is rejected. As shown in Table 10, the test resulted in a significant level of 0.443 .

\section{The results of economic exposure dimension}

Economic exposure is related to the risk that is generated from dealing with foreign currencies in the long run.

This section tests the hypotheses concerning the relationship between a firm's specific characteristics and the use of risk management techniques concerning economic exposure.

Like transaction exposure, economic exposure management techniques were coded depending on how often these techniques were used by firms. If a technique was always used by the respondent, the code was (5); if it was usually used, the code was (4); if it was sometimes used, the code was (3); if it was seldom used, the code was (2); and if the technique was never used, the code was (1). ANOVA was used to test the hypotheses.

Results depending on each character are presented next. 
Table 9: Percentage of foreign debt to total debt effect on transaction exposure risk (1) management

\begin{tabular}{|c|c|c|c|c|c|c|c|c|}
\hline \multirow{2}{*}{$\begin{array}{l}\text { Percentage of } \\
F D / T D\end{array}$} & \multirow[t]{2}{*}{$N$} & \multirow{2}{*}{ Mean } & \multirow{2}{*}{$\begin{array}{l}\text { Standard } \\
\text { deviation }\end{array}$} & \multirow{2}{*}{$\begin{array}{l}\text { Standard } \\
\text { error }\end{array}$} & \multicolumn{2}{|c|}{95 per cent confidence interval for mean } & \multirow[t]{2}{*}{ Minimum } & \multirow[t]{2}{*}{ Maximum } \\
\hline & & & & & Lower bound & Upper bound & & \\
\hline 0 & 12 & 2.5455 & 1.32130 & 0.38143 & 1.7060 & 3.3851 & 1.00 & 4.40 \\
\hline 10 & 1 & 4.3333 & - & - & - & - & 4.33 & 4.33 \\
\hline 20 & 6 & 3.3681 & 0.37120 & 0.15154 & 2.9785 & 3.7576 & 3.00 & 4.00 \\
\hline 30 & 3 & 3.3394 & 0.60311 & 0.34821 & 1.8412 & 4.8376 & 2.82 & 4.00 \\
\hline 40 & 8 & 3.7397 & 0.74113 & 0.26203 & 3.1201 & 4.3593 & 2.73 & 5.00 \\
\hline 50 & 4 & 2.5000 & 0.00000 & 0.00000 & 2.5000 & 2.5000 & 2.50 & 2.50 \\
\hline 60 & 1 & 3.3636 & - & - & - & - & 3.36 & 3.36 \\
\hline 70 & 2 & 4.0909 & 1.28565 & 0.90909 & -7.4602 & 15.6420 & 3.18 & 5.00 \\
\hline 80 & 2 & 3.2455 & 1.19565 & 0.84545 & -7.4971 & 13.9880 & 2.40 & 4.09 \\
\hline \multirow[t]{2}{*}{ Total } & 39 & 3.1554 & 1.02638 & 0.16435 & 2.8227 & 3.4881 & 1.00 & 5.00 \\
\hline & & & \multicolumn{2}{|c|}{ Sum of squares } & d.f. & Mean square & $F$ & Significant \\
\hline \multicolumn{3}{|c|}{ Between groups } & \multicolumn{2}{|l|}{12.483} & 8 & 1.560 & 1.699 & 0.140 \\
\hline \multicolumn{3}{|c|}{ Within groups } & \multicolumn{2}{|l|}{27.548} & 30 & 0.918 & - & - \\
\hline \multicolumn{3}{|l|}{ Total } & \multicolumn{2}{|l|}{40.031} & 38 & - & - & - \\
\hline
\end{tabular}

Firm size

The hypothesis was as follows:

H05: There is a significant statistical relationship between firm size and management practices and economic exposure in the Jordanian environment.

The variables used to measure this character were sales volume and capital size. The one-way ANOVA results for each variable are presented next.

(a) The effect of the capital size of a firm on managing economic exposure risk

Table 11 shows a significant statistical relationship between the capital size of a firm and the techniques used to manage economic exposure, with a significance level of 0.0001 .

(b) The effect of the sales volume of a firm on managing economic exposure risk

The result of the test shows a significant statistical relationship concerning this variable. The significance level is 0.001 for this test, as shown in Table 12.

Both capital and sales tests show significant statistical relationships with the degree of using the management techniques to handle economic exposure. Thus, H06 is substantiated concerning the relationship between firm size and its management of economic exposure. 
Table 10: Legal structure effect on transaction exposure risk management

\begin{tabular}{|c|c|c|c|c|c|c|c|c|c|}
\hline \multirow[t]{2}{*}{ Legal structure } & \multirow[t]{2}{*}{$N$} & \multirow[t]{2}{*}{ Mean } & \multirow{2}{*}{$\begin{array}{l}\text { Standard } \\
\text { deviation }\end{array}$} & \multirow{2}{*}{$\begin{array}{l}\text { Standard } \\
\text { error }\end{array}$} & \multicolumn{3}{|c|}{$95 \%$ confidence interval for mean } & \multirow[t]{2}{*}{ Minimum } & \multirow[t]{2}{*}{ Maximum } \\
\hline & & & & & Lower bound & Upper bound & & & \\
\hline Public shareholding & 12 & 3.4868 & 0.77937 & 0.22499 & 2.9916 & 3.9820 & & 2.00 & 5.00 \\
\hline Private shareholding & 3 & 2.7697 & 0.39263 & 0.22669 & 1.7943 & 3.7450 & & 2.40 & 3.18 \\
\hline Partnership & 3 & 3.6263 & 0.40693 & 0.23494 & 2.6154 & 4.6371 & & 3.33 & 4.09 \\
\hline Limited liability & 15 & 2.9539 & 1.38090 & 0.35655 & 2.1892 & 3.7186 & & 1.00 & 5.00 \\
\hline Private company & 5 & 2.7000 & 0.44721 & 0.20000 & 2.1447 & 3.2553 & & 2.50 & 3.50 \\
\hline \multirow[t]{2}{*}{ Total } & 38 & 3.1273 & 1.02487 & 0.16626 & 2.7905 & 3.4642 & & 1.00 & 5.00 \\
\hline & & \multicolumn{2}{|c|}{ Sum of squares } & d.f. & \multicolumn{2}{|c|}{ Mean square } & $F$ & & Significant \\
\hline \multicolumn{2}{|l|}{ Between groups } & \multicolumn{2}{|l|}{4.046} & 4 & \multicolumn{2}{|l|}{1.011} & \multicolumn{2}{|c|}{0.959} & 0.443 \\
\hline \multicolumn{2}{|l|}{ Within groups } & \multicolumn{2}{|l|}{34.818} & 33 & \multicolumn{2}{|l|}{1.055} & \multicolumn{2}{|l|}{-} & - \\
\hline Total & & 38.863 & & 37 & - & & - & & - \\
\hline
\end{tabular}

Table 11: The effect of capital size on managing economic exposure risk

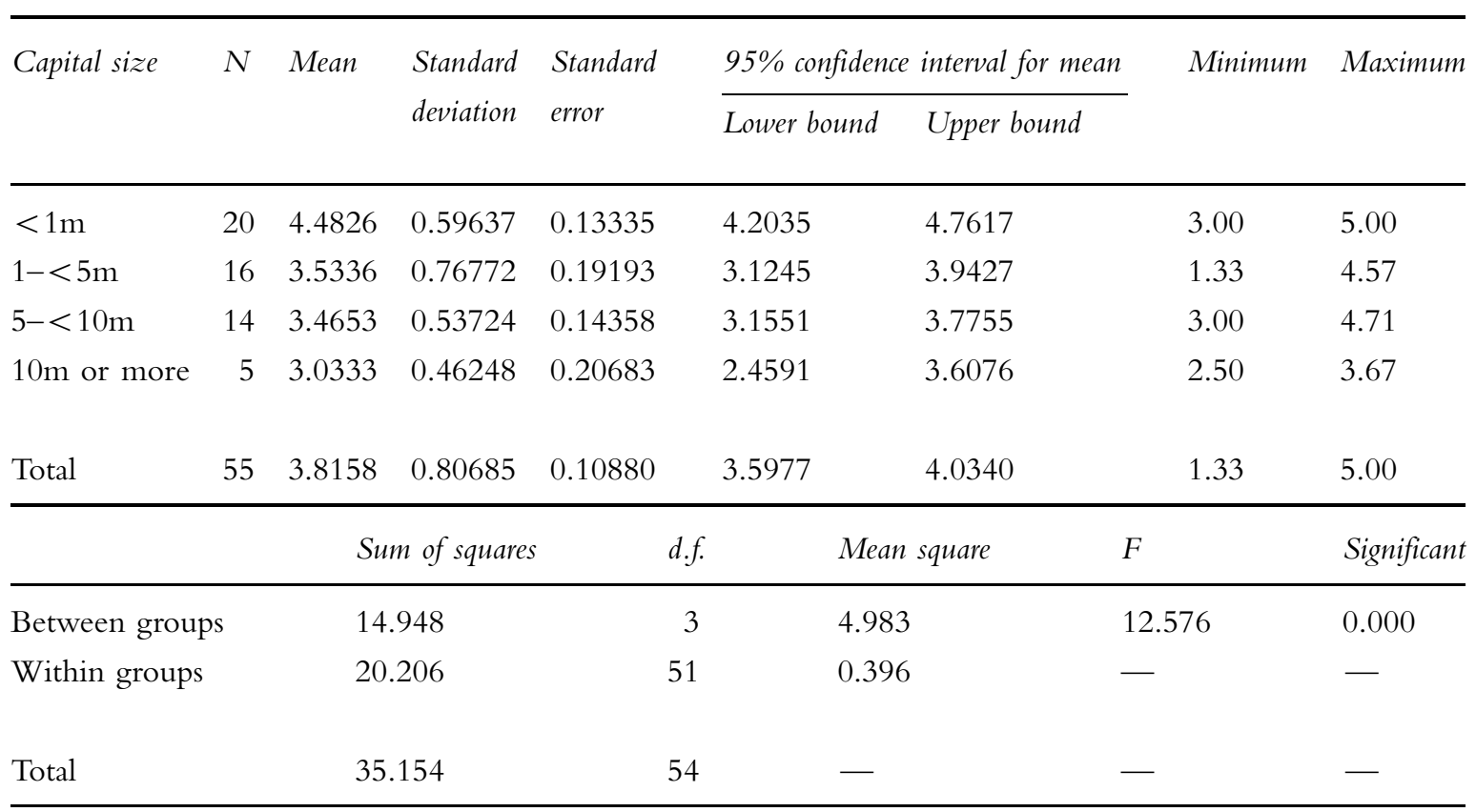


Table 12: The effect of sales volume on managing economic exposure risk

\begin{tabular}{|c|c|c|c|c|c|c|c|c|c|}
\hline \multirow[t]{2}{*}{ Sales volume } & \multirow[t]{2}{*}{$N$} & \multirow[t]{2}{*}{ Mean } & \multirow{2}{*}{$\begin{array}{l}\text { Standard } \\
\text { deviation }\end{array}$} & \multirow{2}{*}{$\begin{array}{l}\text { Standard } \\
\text { error }\end{array}$} & \multicolumn{3}{|c|}{$95 \%$ confidence interval for mean } & \multirow[t]{2}{*}{ Minimum } & \multirow[t]{2}{*}{ Maximum } \\
\hline & & & & & & Lower bound & Upper bound & & \\
\hline$<3 \mathrm{~m}$ & 16 & 4.3905 & 0.88562 & 0.22141 & & 3.9186 & 4.8624 & 1.33 & 4.86 \\
\hline $3-<6 \mathrm{~m}$ & 17 & 3.4529 & 0.57337 & 0.13906 & & 3.1581 & 3.7477 & 2.00 & 4.17 \\
\hline $6-<9 m$ & 9 & 3.1296 & 0.41481 & 0.13827 & & 2.8108 & 3.4485 & 2.50 & 4.00 \\
\hline $9-<12 \mathrm{~m}$ & 4 & 3.3917 & 0.23154 & 0.11577 & & 3.0232 & 3.7601 & 3.20 & 3.67 \\
\hline $13-<15 \mathrm{~m}$ & 2 & 3.4286 & 0.60609 & 0.42857 & & -2.0169 & 8.8741 & 3.00 & 3.86 \\
\hline $15 \mathrm{~m}$ or more & 4 & 3.2500 & 0.44096 & 0.22048 & & 2.5483 & 3.9517 & 2.83 & 3.83 \\
\hline \multirow[t]{2}{*}{ Total } & 52 & 3.6642 & 0.79678 & 0.11049 & & 3.4424 & 3.8860 & 1.33 & 4.86 \\
\hline & & \multicolumn{2}{|c|}{ Sum of squares } & & d.f. & \multicolumn{2}{|c|}{ Mean square } & $F$ & Significant \\
\hline \multicolumn{2}{|c|}{ Between groups } & \multicolumn{2}{|c|}{12.865} & \multicolumn{2}{|r|}{5} & \multicolumn{2}{|c|}{2.573} & 6.065 & 0.000 \\
\hline \multicolumn{2}{|l|}{ Within groups } & \multicolumn{2}{|c|}{19.513} & & 46 & \multicolumn{2}{|c|}{0.424} & - & - \\
\hline Total & & \multicolumn{2}{|c|}{32.378} & & 51 & \multicolumn{2}{|l|}{-} & - & - \\
\hline
\end{tabular}

Table 13: The effect of firm's sector on economic exposure risk

\begin{tabular}{|c|c|c|c|c|c|c|c|c|c|}
\hline \multirow[t]{2}{*}{ Firm's sector } & \multirow[t]{2}{*}{$N$} & \multirow[t]{2}{*}{ Mean } & \multirow{2}{*}{$\begin{array}{l}\text { Standard } \\
\text { deviation }\end{array}$} & \multirow{2}{*}{\multicolumn{2}{|c|}{$\begin{array}{l}\text { Standard } \\
\text { error }\end{array}$}} & \multicolumn{2}{|c|}{ 95\% confidence interval for mean } & \multirow[t]{2}{*}{ Minimum } & \multirow[t]{2}{*}{ Maximum } \\
\hline & & & & & & Lower bound & Upper bound & & \\
\hline Manufacturing & 26 & 3.3736 & 0.76520 & 0.15007 & & 3.0646 & 3.6827 & 1.33 & 4.83 \\
\hline $\begin{array}{l}\text { Wholesale and } \\
\text { retail trade }\end{array}$ & 29 & 4.1319 & 0.76916 & 0.14283 & & 3.8393 & 4.4244 & 2.50 & 5.00 \\
\hline Others & 2 & 3.0833 & 0.35355 & 0.25000 & & -0.0932 & 6.2599 & 2.83 & 3.33 \\
\hline \multirow[t]{2}{*}{ Total } & 57 & 3.7492 & 0.84651 & 0.11212 & & 3.5246 & 3.9738 & 1.33 & 5.00 \\
\hline & & \multicolumn{2}{|c|}{ Sum of squares } & \multicolumn{2}{|r|}{ d.f. } & \multicolumn{2}{|c|}{ Mean square } & $F$ & Significant \\
\hline \multicolumn{2}{|l|}{ Between groups } & \multicolumn{2}{|c|}{8.801} & \multicolumn{2}{|r|}{2} & \multicolumn{2}{|c|}{4.400} & 7.585 & 0.001 \\
\hline \multicolumn{2}{|l|}{ Within groups } & \multicolumn{2}{|c|}{31.328} & \multicolumn{2}{|r|}{54} & \multicolumn{2}{|c|}{0.580} & - & - \\
\hline Total & & \multicolumn{2}{|c|}{40.129} & & 56 & \multicolumn{2}{|l|}{ - } & - & - \\
\hline
\end{tabular}


Table 14: Percentage of foreign sales to total sales effect on economic exposure currency risk management

\begin{tabular}{|c|c|c|c|c|c|c|c|c|c|}
\hline \multirow{2}{*}{$\begin{array}{l}\text { Percentage of } \\
F S / T S\end{array}$} & \multirow[t]{2}{*}{$N$} & \multirow[t]{2}{*}{ Mean } & \multirow{2}{*}{$\begin{array}{l}\text { Standard } \\
\text { deviation }\end{array}$} & \multirow{2}{*}{$\begin{array}{l}\text { Standard } \\
\text { error }\end{array}$} & \multicolumn{3}{|c|}{$95 \%$ confidence interval for mean } & \multirow[t]{2}{*}{ Minimum } & \multirow[t]{2}{*}{ Maximum } \\
\hline & & & & & & Lower bound & Upper bound & & \\
\hline 10 & 2 & 3.0000 & 0.00000 & 0.00000 & & 3.0000 & 3.0000 & 3.00 & 3.00 \\
\hline 20 & 3 & 3.0000 & 0.60093 & 0.34694 & & 1.5072 & 4.4928 & 2.50 & 3.67 \\
\hline 30 & 3 & 3.0556 & 1.49381 & 0.86245 & & -0.6553 & 6.7664 & 1.33 & 4.00 \\
\hline 40 & 9 & 3.4630 & 0.51301 & 0.17100 & & 3.0686 & 3.8573 & 2.83 & 4.33 \\
\hline 50 & 8 & 3.4000 & 0.89389 & 0.31604 & & 2.6527 & 4.1473 & 2.00 & 4.83 \\
\hline 60 & 2 & 3.2500 & 0.35355 & 0.25000 & & 0.0734 & 6.4266 & 3.00 & 3.50 \\
\hline 70 & 6 & 3.5167 & 0.49610 & 0.20253 & & 2.9960 & 4.0373 & 3.00 & 4.33 \\
\hline 80 & 7 & 4.1327 & 0.91884 & 0.34729 & & 3.2829 & 4.9824 & 3.00 & 4.86 \\
\hline 100 & 6 & 3.7857 & 0.58902 & 0.24046 & & 3.1676 & 4.4038 & 3.00 & 4.71 \\
\hline \multirow[t]{2}{*}{ Total } & 54 & 3.6612 & 0.79521 & 0.10821 & & 3.4441 & 3.8783 & 1.33 & 4.86 \\
\hline & & \multicolumn{3}{|c|}{ Sum of squares } & d.f. & \multicolumn{2}{|c|}{ Mean square } & $F$ & Significant \\
\hline \multicolumn{2}{|c|}{ Between groups } & \multicolumn{2}{|c|}{11.808} & \multicolumn{2}{|r|}{9} & \multicolumn{2}{|c|}{1.312} & 2.659 & 0.015 \\
\hline \multicolumn{2}{|c|}{ Within groups } & \multicolumn{2}{|c|}{21.708} & \multicolumn{2}{|r|}{44} & \multicolumn{2}{|c|}{0.493} & - & - \\
\hline \multicolumn{2}{|l|}{ Total } & \multicolumn{2}{|c|}{33.515} & & 53 & \multicolumn{2}{|c|}{ - } & - & - \\
\hline
\end{tabular}

(2) The effect of firm sector on managing economic exposure risk

H06: There is a significant statistical relationship between industry groupings and management practices and economic exposure in the Jordanian environment.

Table 13 shows that there is a significant statistical relationship between sector of a firm and its management of economic exposure. The significant level of 0.001 asserts this relationship and H06 is substantiated.
The results show that the strongest attitude toward adopting the managerial techniques was for wholesale and retail trade, as the mean is 4.13. This is followed by manufacturing, with a mean of 3.37 .

(3) The effect of international involvement on managing economic exposure

In this section, we tested the following hypothesis:

H07: There is a significant statistical relationship between international business activity level and 
Table 15: Percentage of foreign costs to total costs effect on economic exposure risk management

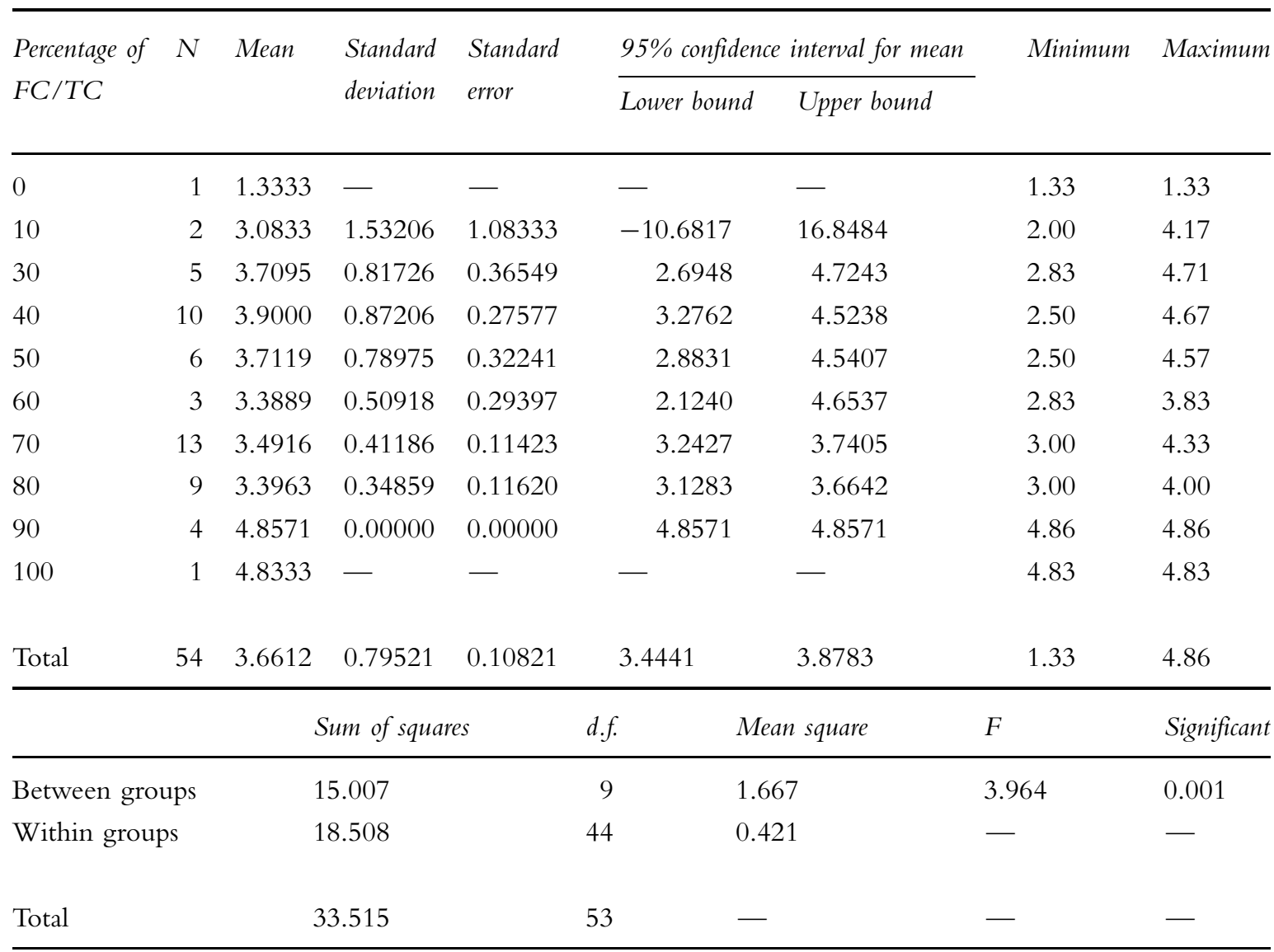

management practices and economic exposure in the Jordanian environment.

As mentioned earlier, this characteristic is measured using three variables. The results for each variable are presented next.

(a) The effect of percentage of foreign sales to total sales on economic exposure risk management

With significance value equalling 0.015 , the percentage of foreign sales to total sales has a significant statistical relationship with the use of management techniques. This is clearly shown in Table 14. (b) The effect of percentage of foreign costs to total costs on economic exposure risk management

In addition, with significance value equalling 0.001, the percentage of the foreign costs to the total costs has a significant relationship with the use of management techniques. This is shown in Table 15.

(c) The effect of percentage of foreign debt to total debt on economic exposure risk management

Finally, the test of the relation between the percentage of foreign debt to total debt and the managerial actions toward economic exposure reveal a significant statistical relationship. The 
Table 16: Percentage of foreign debt to total debt effect on economic exposure risk management

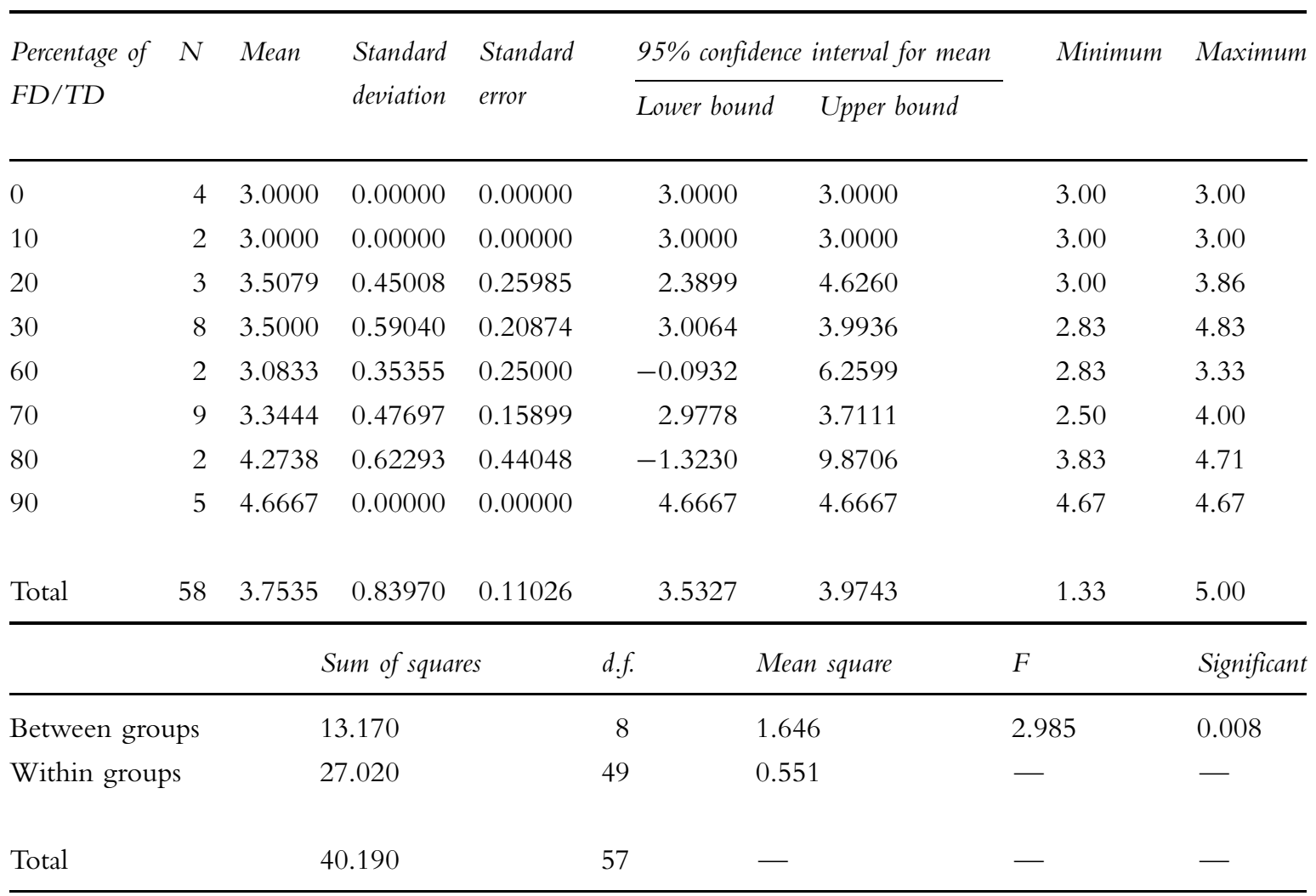

significance figure is 0.008 , which is demonstrated in Table 16.

The results of the previous three tests assert the acceptance of the relation between the degree of international involvement of a firm and its management of the economic exposure. Therefore, H07 is substantiated. In addition, an indication of a stronger attitude toward using the managerial techniques moving to higher levels of foreign sales, costs, and debts is seen by reviewing the means.

(4) The effect of legal structure on foreign economic exposure risk management

The hypothesis is as follows:
H08: There is a significant statistical relationship between legal structure and management practices and economic exposure risk in the Jordanian environment.

The test was performed to ascertain whether there is a relationship between the legal structure of a firm (as a character) and the management techniques used in handling economic exposure risk. The results show a significant statistical relationship under a significance level of 0.001. Therefore, H08 is also accepted, as shown in Table 17.

The results show that the strongest attitude toward adopting the managerial techniques was 
Table 17: Legal structure effect on economic exposure risk management

\begin{tabular}{|c|c|c|c|c|c|c|c|c|c|}
\hline \multirow[t]{2}{*}{ Legal structure } & \multirow[t]{2}{*}{$N$} & \multirow[t]{2}{*}{ Mean } & \multirow{2}{*}{$\begin{array}{l}\text { Standard } \\
\text { deviation }\end{array}$} & \multirow{2}{*}{$\begin{array}{l}\text { Standard } \\
\text { error }\end{array}$} & \multicolumn{3}{|c|}{$95 \%$ confidence interval for mean } & \multirow[t]{2}{*}{ Minimum } & \multirow[t]{2}{*}{ Maximum } \\
\hline & & & & & Lower bound & Upper bound & & & \\
\hline Public shareholding & 16 & 3.1979 & 0.53451 & 0.13363 & 2.9131 & 3.4827 & & 2.00 & 4.17 \\
\hline Private shareholding & 6 & 3.6000 & 0.58310 & 0.23805 & 2.9881 & 4.2119 & & 2.83 & 4.33 \\
\hline Partnership & 7 & 4.5476 & 0.71824 & 0.27147 & 3.8834 & 5.2119 & & 3.50 & 5.00 \\
\hline Limited liability & 27 & 3.9730 & 0.84504 & 0.16263 & 3.6387 & 4.3073 & & 1.33 & 4.86 \\
\hline Private company & 1 & 2.5000 & - & - & - & - & & 2.50 & 2.50 \\
\hline \multirow[t]{2}{*}{ Total } & 57 & 3.7609 & 0.84527 & 0.11196 & 3.5366 & 3.9852 & & 1.33 & 5.00 \\
\hline & & \multicolumn{2}{|c|}{ Sum of squares } & d.f. & \multicolumn{2}{|c|}{ Mean square } & $F$ & & Significant \\
\hline \multicolumn{2}{|l|}{ Between groups } & \multicolumn{2}{|l|}{12.364} & 4 & \multicolumn{2}{|l|}{3.091} & \multicolumn{2}{|c|}{5.814} & 0.001 \\
\hline \multicolumn{2}{|l|}{ Within groups } & \multicolumn{2}{|l|}{27.647} & 52 & \multicolumn{2}{|l|}{0.532} & \multicolumn{2}{|l|}{-} & - \\
\hline Total & & 40.011 & & 56 & - & & - & & - \\
\hline
\end{tabular}

for partnerships, as the mean is 4.54. This is followed by limited liabilities firms, with a mean of 3.97 and private and public shareholdings firms, with means of 3.60 and 3.19, respectively.

\section{Usage levels of different managerial techniques by Jordanian firms}

Other results describe the usage levels of each foreign currency risk management technique in each dimension, that is, transaction and economic exposures. Tables 18 and 19 show the means and standard deviations for each technique.

Techniques to deal with transaction exposure were classified in terms of sophistication level into three groups. The highest sophisticated level in terms of cost and risk is that of derivatives, which are forward, future, options, and swap contracts. The low value of mean of the various hedging techniques suggests a low usage level of these techniques by firms. Forward contracts had the highest mean relative to this group, with 3.32 .

The second group, which has a relatively moderate risk and cost hedging level, is shortterm borrowing and deposit. A stronger attitude toward using these techniques is indicated by the higher means in the table, with 3.40 for the short-term deposits and 3.57 for short-term borrowing.

Finally, the last group of techniques, in which the management hedges the cost and risk internally, without involving a third party, is considered the least sophisticated. The technique with the highest level of usage is the pricing policy, with a mean of 4.61 , followed by the domestic currency, with 4.50. The technique 
Table 18: Level of using the following hedging instrument to manage foreign exchange risk (transaction exposure)

\begin{tabular}{llll}
\hline Hedging instrument & Mean & $N$ & Standard deviation \\
\hline Forward contracts & 3.32 & 34 & 1.28 \\
Future contracts & 3.25 & 25 & 1.10 \\
Option contracts & 3.17 & 18 & 1.35 \\
Swap contracts & 3.00 & 17 & 0.98 \\
Short-term borrowing & 3.57 & 23 & 1.04 \\
Short-term deposits & 3.40 & 23 & 1.40 \\
Pricing policy & 4.61 & 31 & 0.77 \\
Using domestic currency & 4.50 & 25 & 1.00 \\
Netting & 3.50 & 23 & 1.10 \\
Leading and lagging & 3.61 & 17 & 1.08 \\
Matching & 4.11 & 24 & 1.05 \\
Other methods & 4.35 & 4 & 1.22 \\
\hline
\end{tabular}

Table 19: Level of using the following hedging instrument to manage foreign exchange risk (economic exposure)

\begin{tabular}{lcc}
\hline Hedging technique & Mean & $\begin{array}{r}\text { Standard } \\
\text { deviation }\end{array}$ \\
\hline Sourcing inputs in the same currencies as sales are made & 3.27 & 1.25712 \\
Altering the currency from which inputs are sourced, following & 3.45 & 1.24025 \\
movement in foreign exchange rates & & \\
Altering the currency in which production occur, following & 4.71 & 0.75020 \\
movements in foreign exchange rates & & \\
Foreign currency denominated debt & 3.75 & 1.21873 \\
Diversifying sales in many different currencies & 3.72 & 1.11496 \\
Long-term derivatives & 3.32 & 1.09515 \\
\hline
\end{tabular}

with the least usage in that group is netting, with a mean of 3.50 .

Generally, the results show that the higher the sophistication level of the technique in terms of risk and cost, the lower the level of usage.
Table 19 shows the usage level of techniques to deal with economic exposure. The technique with the highest usage level, with a mean of 4.71 , is altering the currency, in which the production cost occurs, following movements in 
Table 20: The reasons behind not using one or more of the managing techniques (transaction exposure)

\begin{tabular}{lcr}
\hline Reason & Frequency & Valid \% \\
\hline Too complex and there is no trained staff to deal with this & 15 & 33.4 \\
kind of risk & 5 & 11.1 \\
Not allowed & 6 & 13.3 \\
Instruments are not available & 3 & 6.6 \\
Not logical to manage foreign exchange risk & 16 & 35.6 \\
Other reasons & & 100.0 \\
& 45 & \\
Total & &
\end{tabular}

Table 21: The reasons behind not using one or more of the managing technique (economic exposure)

\begin{tabular}{lcr}
\hline Reason & Frequency & Valid \% \\
\hline Instruments are not available & 8 & 14.5 \\
Too complex and there is no trained staff to deal with this risk & 4 & 7.3 \\
Not allowed & 7 & 12.7 \\
Not logical to manage foreign exchange risk & 3 & 5.5 \\
The pegged JD to the US dollar gave the firm a stable position & 33 & 60.0 \\
& & \\
Total & 55 & 100.0 \\
\hline
\end{tabular}

foreign exchange rates. Foreign currency denominated debt and diversifying sales in many different currencies, with means of 3.75 and 3.72, respectively. Altering the currency from which inputs are sourced following movement in foreign exchange rates had a mean of 3.45. Finally, the use of long-term derivatives and the technique of sourcing inputs in the same currencies as those in which sales are made had the lowest means, with 3.32 and 3.27, respectively.

\section{Reasons behind not using the managerial techniques by Jordanian firms}

Firms were asked about the reasons behind not using the different techniques mentioned in the questionnaire.

The results for the transaction dimension are presented in Table 20. It is clear that the majority of the respondents (33.4 per cent) consider complexity and lack of experience to be two of the problems that stand against adopting some of the techniques. 35.6 per cent 
of respondents stated other reasons for not using the techniques: the majority answered that their transactions have a certain stability due to the Jordanian dinar being pegged to the US dollar. Others added that as they gain from the volatility of currency they accept a certain level of loss, otherwise the firm limits that loss through reflecting the differences to the prices. 11.1 per cent of the respondents said they do not use the techniques simply because they do not have the authority to do so, while 13.3 per cent believe that those instruments do not exist or are not available. In this section, the implied instruments are the derivatives because the other instruments are natural and do not need a second party in order to use them. Finally, 6.6 per cent of respondents said they do not believe in the rationality behind managing transaction exposure.

The same questions were asked again but they this time were concerned with the reasons behind not using the different techniques to manage economic exposure. The results are as shown in Table 21.

The pegging of the Jordanian dinar to the US dollar gives stability to firms toward the movement of the currencies. The majority of respondents therefore believe there is no need to act to this exposure.

In addition, the results show that 14.5 per cent of respondents believe that the instruments are not available in the Jordanian environment. 7.3 per cent believe that using these techniques is overly complex and that staff lack the experience to use them. On the other hand, 12.7 per cent of respondents do not use the techniques because they do not have the authority to do so. Finally, 5.5 per cent do not believe in the relevance of managing foreign currency risk.

\section{CONCLUSIONS}

Motivated by the fact that foreign currency risk becomes more and more important in the light of the globalisation and internationalisation, this study was conducted in order to gain insight into the management of foreign currency risk by Jordanian firms. In addition, it examined the impact of firm-specific characteristics and their relationship with the managerial techniques used to face that risk with respect to two dimensions: transaction and economic exposures. The specific factors of a firm included size, sector, legal structure, and international involvement.

The results of the questionnaire give an idea about Jordan's economic environment in terms of comprehension, exposure, and management of foreign currency risk.

Evidence from the analysis shows that 66 per cent of the firms do manage their foreign currency risk. The majority of the firms rely, however, on natural hedging techniques, and the use of more sophisticated techniques such as financial derivatives is not common practice by Jordanian firms.

The lack of knowledge in managers and other staff members in management is one of the major obstacles for the use of the techniques. Some firms do not believe in the relevance of their exposure to foreign currency risk. Others believe that financial derivatives are not available in the Jordanian market. Financial derivatives do, however, exist in some major Jordanian banks.

The great majority of firms considered the pegged Jordanian dinar to the US dollar one of the reasons that gave their foreign transactions a certain level of stability, since both currencies move in the same direction with approximately the same proportion. Dealing with other currencies that are subject to volatility in their exchange rates respect 
to the Jordanian dinar as the euro needs substantial effort to manage.

Concerning the firm-specific characteristics and their hypothesised relationship to the management of transaction exposure dimension, this study shows that there is no relationship between a firm size and the management practices toward transaction exposure. The same result was shown for a firm's legal structure.

The relationship between a firm's different sectors and the hedging techniques used was significant, and the highest attitude was in the manufacturing sector. The study also found that a firm's international involvement and management practices positively correlated.

On the other hand, the results concerning the firm-specific characteristics and their relationship to the managerial techniques used toward economic exposure were as follows:

Firm size negatively correlated to the management practices. This result could be attributed to the fact that larger firms have less flexibility to act toward economic exposure. The operational hedging techniques are expensive and risky because they involve a large amount of resources. Shifting the industry from one currency to another is one example for techniques that need to adopt major resources. In addition, larger firms may be engaged in long-term contracts that take into consideration the foreign currency volatility risk.

The evidence also found a correlation between a firm's sector and its management practices: commercial firms had the strongest attitude toward managing economic exposure. Moreover, a relationship between the legal structure of a firm and its management to economic exposure was found to be significant. Partnerships seemed to have a higher adoption rate of the managerial techniques than other types of entities. This can be attributed to the fact that the owners of a firm have more motive and authority to make decisions involving business than managers in other legal structures.

A firm's degree of international involvement and its management practices positively correlated.

\section{RECOMMENDATIONS}

Based on the results of the study, some recommendations are stated as follows:

(1) Proper training programmes should be conducted for financial managers in order to enhance their knowledge about the importance of foreign currency risk and the different techniques used to manage that risk.

(2) Many of the Jordanian firms attributed the absence of the hedging techniques in their firms to the exchange rate policy of the CBJ (Central Bank of Jordan). This policy gives firms a stable position toward the JD/\$US exchange rate changes. Jordanian firms must, however, be conscious of the fact that the JD may be floated against the US dollar in the future. In this case, the magnitude of the foreign currency exposure will be very high and will need effective foreign currency risk management practices.

(3) Banks and other financial firms should play a vital role in handling of risk management issues. Financial derivatives should be offered and promoted more. In addition, consulting services should be provided to manage such risk.

(4) Specialised financial firms that offer a wide range of financial instruments to hedge 
foreign currency risk and that also provide well-experienced staff familiar with Jordan's economic environment should be established. Furthermore, the experiences of such specialised firms in developed countries must be benefited from.

\section{References and Notes}

1 Jonuska, M. and Samenaite, I. (2003) 'Foreign Exchange Risk Management in Lithuanian Economy: The Use of Currency Derivatives', Published Master Thesis, Stockholm School of Economics in Riga, Available online.

2 Allayannis, G., Brown, G. and Klapper, L. (2001) 'Exchange Rate Risk Management Evidence from East Asia', Policy Research Working Paper, No. 2606, The World Bank, Available online: http:// www-wds.worldbank.org/external/default/ WDSContentServer/IW3P/IB/2001/06/15/ 000094946_01060604005427/Rendered/PDF/ multi0page.pdf.

3 Karasoy, A. (1995) 'Management of Exchange Rate Risk in Turkish Banking Sector: A Model and Tests', Discussion Paper, No. 9602, Central Bank of the Republic of Turkey, Available online: http:// www.tcmb.gov.tr/research/discus/9602eng.pdf.

4 Bradley, K. and Moles, P. (2001) 'The Effects of Exchange Rate Movements on Non-financial UK Firms', International Business Review, Vol. 10, pp. 51-69.
5 El-Masry, A. (2003) 'The Exchange Rate Exposure of UK Non-financial Companies: Industry Level Analysis', Journal of Managerial Finance, Vol. 32, No. 2, pp. 115-136.

6 Fang, W. and Miller, S. (2004) 'Exchange Rate Depreciation and Exports: The Case of Singapore', Working Paper, No. 2004-45, University of Connecticut, Available online: http://www. econ.uconn.edu/working/2004-45.pdf.

7 Belk, P.A and Glaum, M. (1990) 'The Management of Foreign Exchange Risk in UK Multinationals: An Empirical Investigation', Accounting and Business Research, Vol. 21, No. 81, pp. 3-13.

8 Batten, J., Mellor, R. and Wan, V. (1993) 'Foreign Exchange Risk Management Practices and Products Used by Australian Firms', Journal of International Business Studies, Vol. 25, pp. 557-573.

9 Brucaite, V. and Yan, S. (2000) 'Financial Risk Management - Case Studies with SKF and Elof Hansson', Published Master Thesis, Göteborg University, Available online: http://www. handels.gu.se/epc/archive/00001538/01/ Brucaite_200014.pdf.

10 Dhanani, A. and Groves, R. (2001) 'The Management of Strategic Exchange Risk: Evidence from Corporate Practices', Accounting and Business Research, Vol. 31, No. 4, pp. 275-290.

11 Popov, V. and Stutzmann, Y. (2003) 'How is Foreign Exchange Risk Managed? An Empirical Study to Two Swiss Companies', Published Master Thesis, University of Lausanne, Available online: http://www.hec.unil.ch/cms_mbf/master_thesis/ 0314.pdf.

12 Company statistics. Main Economic Sectors, Jordan Companies Control Department, Available online: www.ccd.gov.jo. 